Article

\title{
Initial Survival and Development of Planted European Beech (Fagus sylvatica L.) and Small-Leaved Lime (Tilia cordata Milc.) Seedlings Competing with Black Cherry (Prunus serotina EHRH.)
}

\author{
Sarah L. Hasstedt $1, *(\mathbb{D})$ and Peter Annighöfer ${ }^{2}$ \\ 1 Department of Silviculture and Forest Ecology of the Temperate Zones, Georg August University of \\ Göttingen, Büsgenweg 1, 37077 Göttingen, Germany \\ 2 Forest and Agroforest Systems, Technical University of Munich (TUM), Hans-Carl-von-Carlowitz-Platz 2, \\ 85354 Freising, Germany; peter.annighoefer@tum.de \\ * Correspondence: Sarah-Lena.Hasstedt@forst.uni-goettingen.de; Tel.: +49-551-393-3674
}

Received: 16 April 2020; Accepted: 25 May 2020; Published: 27 May 2020

\begin{abstract}
Black cherry (Prunus serotina Енкн.) is considered one of the most invasive tree species in central Europe and causes problems for both nature conservation and silviculture. Besides mechanical control treatments, a suggested control method to prevent its ongoing spread is to underplant shade-tolerant native tree species. Therefore, we combined two mechanical treatments, with underplanting of European beech (Fagus sylvatica L.) or small-leaved lime (Tilia cordata MitL.) on fenced and unfenced plots. After the first growing season, survival rates were evaluated, and selected seedlings were destructively harvested to analyze their growth performance and leaf morphology in association with the different light regimes resulting from mechanical treatments Survival rates for both seedlings were very high $(>95 \%)$. Survival rates were higher on fenced plots than on unfenced plots, most likely as result of browsing. The mortality of $F$. sylvatica decreased with increasing light availability on fenced plots. The mortality of $T$. cordata did not change along the light gradient. After one vegetation period no differences with respect to biomass allocation could be detected along the light gradient. However, the specific leaf areas of both species responded similarly, decreasing with increasing light availability. In summary, both species were able to establish and survive in the dense $P$. serotina understory and might have the potential to outcompete the invasive alien species in the long run.
\end{abstract}

Keywords: invasive species; black cherry management; light availability; seedling mortality; biomass allocation; specific leaf area

\section{Introduction}

Biotic invaders can inflict enormous environmental damage to ecosystems by altering the integrity of their fundamental properties [1]. Invasive plant species affect competition for resources like water or nutrients, and can change the invaded ecosystems' components such as increased biomass production or nitrogen availability and litter production with higher decomposition rates for instance [2]. They are globally recognized as major threats to biodiversity, nature conservation, and ecosystem stability in native forests $[1,3]$. The urgent question, when dealing with any kind of invasive species, is how to handle or control them after their presence is discovered to avoid or minimize possible damage to the ecosystem.

The deciduous tree species black cherry (Prunus serotina EнRн.), native to North America [4], is the largest cherry in its native range [5] and is a valuable furniture wood in the United States [6]. P. serotina 
grows well on a wide variety of soils but grows best on the Allegheny Plateau in the eastern United States of America [5]. With the aim of producing timber of high commercial value [6], the species was introduced to Europe in the early 17th century through France [7,8]. Since the late 18th century, the species has been planted in Germany [9] for several purposes [10]. Aside from producing high quality timber, foresters hoped to improve soil qualities of degraded sites through the species decomposable litter and to reduce the susceptibility of existing pine stands to fire. In addition, P. serotina was planted as fire breaker in highly valuable stands. However, on nutrient-poor sandy soils, the growth forms were disappointing [9] because instead of growing into valuable high-quality timber, stems were often crooked with crotches [11,12]. In many cases, P. serotina that was planted for fire prevention [9], spread uncontrollably and was hence considered a "wood pest" across western Europe [13]. In the 1950s, Belgium and the Netherlands stopped P. serotina plantings, while German foresters continued planting the species until the 1980s [9].

Currently, P. serotina grows from the north of France to Poland, Hungary, and Romania as well as from Denmark to Italy [14] and is one of the most invasive plants in Europe [15]. In Germany, high abundances of $P$. serotina are mainly found in Scots pine (Pinus sylvestris L.) forest stands in Schleswig-Holstein [16], Brandenburg, and Berlin [9], the northern German plain, Rhineland-Palatinate, and also on sandy soils in southern Germany in Bavaria and Baden-Württemberg (Federal Agency for Nature Conservation. Center for German Phytodiversity). The high abundance of this non-native species in managed forests is considered to be a result of long-term planting activities rather than of natural regeneration and dispersal [12]. Once established, efforts to manage and control large affected areas have turned out to be time-consuming, labor and cost intensive, and often ineffective [16-19]. Complete removal of $P$. serotina from forest ecosystems is considered to be nearly impossible [10]. Felled $P$. serotina trees quickly produce stump and root suckers $[5,19,20]$. Girdling the trees seems to be more effective, but is very labor intensive [21]. Under poor light conditions, only minimal radial growth $(<0.06 \mathrm{~mm})$ is observed in P. serotina seedlings [20,22]. However, when light availability suddenly increases due to disturbance-induced canopy gaps (e.g., from thinning, clearing, storm damage), seedlings quickly grow into the new gaps [20]. Due to their growth characteristics, pine forests with relatively low canopy densities are especially susceptible to be invaded by P. serotina. An alternative to mechanical treatments might be to underplant invaded stands with shade-tolerant species to shade-out $P$. serotina over time [23-25]. This control method for $P$. serotina has been applied and tested as a management option for invaded forests in Germany in only a few studies to date [26-28]. A long-term study with underplanted European beech (Fagus sylvatica L.) and Douglas fir (Pseudotsuga menziesii (Mirbel) Franco) [28], has shown the competitive strength of F. sylvatica to survive and grow under $P$. serotina growing in birch stands. Case studies [26-28] showed by high survival that small-leaved lime (Tilia cordata, Mill.) as well as other native shade tolerant tree species such as European hornbeam (Carpinus betulus L.) could also be promising for this purpose. To our knowledge, no study exists that combines underplanting native species with mechanical treatments applied to $P$. serotina.

We planted (fenced and unfenced) 2-year-old, bare-rooted seedlings of F. sylvatica and T. cordata in a managed pine-forest with a pronounced $P$. serotina understory (between 8 and $15 \mathrm{~m}$ in height) in combination with two common mechanical treatments in forest management (felling and girdling). The treatments resulted in different levels of light availability in the understory. Seedlings were monitored during the vegetation period and a representative number was harvested at the end of the vegetation period to evaluate biomass allocation and growth patterns within the plants as reaction to the light regimes. These helps identify appropriate conditions to underplant the seedlings and to maximize their competitive ability against $P$. serotina. The hope is that the native shade tolerant species can at least keep up with the invasive $P$. serotina and shade-out the species in the long run.

Tree growth, driven by photosynthesis, is defined as the increase in total plant dry mass. This mass is allocated in different tree compartments (leaves, branches, stem, roots) [29,30]. This distribution of biomass across the plant provides insight into the plants' growth performance and concomitantly their access to limiting resources such as nutrients, water, and light [29]. The present study focused on 
biomass allocation of underplanted tree-seedlings under different light conditions in order to evaluate their growth performance.

The aims of this survey were (a) to study whether the chosen underplanted tree species survive in the dense P. serotina understory, (b) to relate biomass allocation patterns in the small seedlings to light availability, and (c) to relate specific leaf area to the light available as a result of previously conducted mechanical control-methods applied to the invasive species.

\section{Results}

\subsection{Mortality}

\subsubsection{Seedling Mortality Inside and Outside the Fences}

After the first growing season 2017, the overall mortality of both species was negligible (Table S1 in supplementary material contains a complete dataset on dead seedlings). Of the $2108 \mathrm{~F}$. sylvatica seedlings, 92 died and of the $2062 \mathrm{~T}$. cordata seedlings, 94 died, which equaled an overall mortality of $4.4 \%$ and $4.6 \%$ and indicated no differences in mortality between species (Chi-squared; $p=0.819$ ). For both species, the number of dead seedlings was higher on unfenced plots compared to the fenced plots (F. sylvatica: $p=0.038$ and T. cordata: $p=0.005$ ). No difference between the two species could be detected within $(p=0.946)$ or outside the fences $(p=0.643)$ (Figure 1$)$.

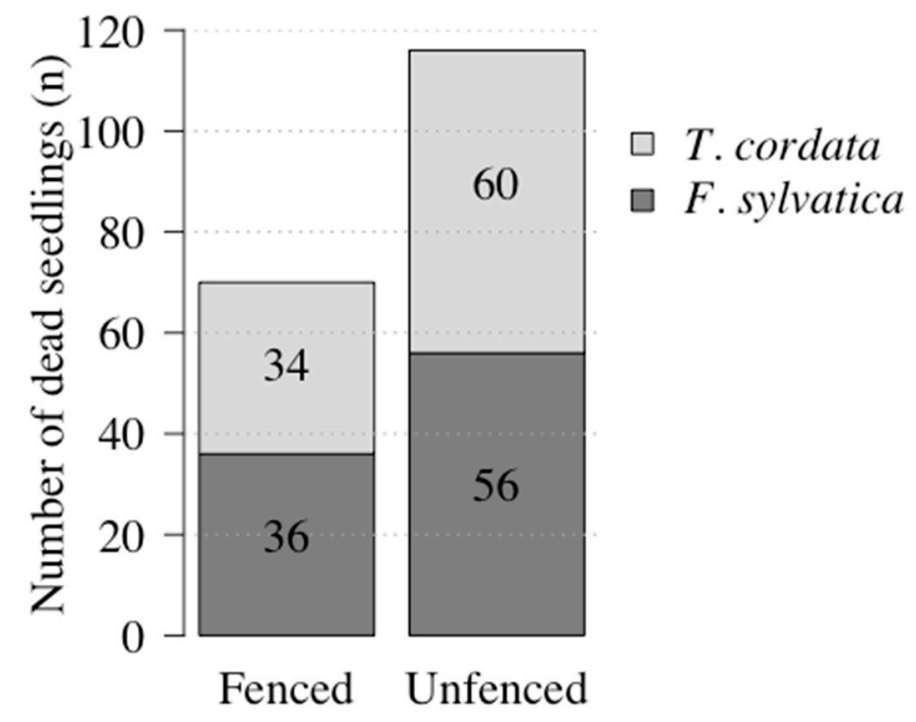

Figure 1. Absolute number of dead Fagus sylvatica and Tilia cordata seedlings on fenced and unfenced plots after the growing season 2017 in the whole experiment.

\subsubsection{Mortality along light gradient}

On average, one seedling died on each plot over the entire field experiment. Note that a single dead seedling represented a mortality of $3.13 \%$ (Table 1 ). The fenced and unfenced plots did not differ in light availability $(p=0.294)$. Thus, the further analysis of mortality and growth performance (seedlings' biomass, compartment mass fraction analysis, and specific leaf area) was restricted to the fenced sites, to exclude an effect of browsing. The correlation between mortality and light availability was only significant for $F$. sylvatica seedlings, with mortality decreasing with increasing light availability (Figure 2a). No correlation between mortality and the light availability (ISF, indirect site factor, Table S3 in supplementary material contains all abbreviations and definitions used in this manuscript) was detected for T. cordata seedlings and the calculated GAM (generalized additive model) was also not significant (Figure 2b). 
Table 1. Mortality per plot for F. sylvatica and T. cordata seedlings after the first growing season. Shown are detected minimum (Min), mean \pm standard deviation (SD), median, and maximum (Max) mortality of dead seedlings on fenced and unfenced plots after the growing season 2017 and associated figures (Ass. figure).

\begin{tabular}{ccccccc}
\hline \multirow{2}{*}{ Species } & \multirow{2}{*}{ Fencing } & \multirow{2}{*}{ Plots $(\boldsymbol{n})$} & \multicolumn{3}{c}{ Mortality Per Plot (\%) } & \multirow{2}{*}{ Ass. Figure } \\
\cline { 3 - 6 } F. sylvatica & Menced & 33 & 0 & Mean \pm SD (Median) & Max & \\
\cline { 2 - 6 } & Unfenced & 33 & 0 & $5.41 \pm 4.38(3.13)$ & 15.63 & Figure 2a \\
\hline \multirow{2}{*}{ T. cordata } & Fenced & 33 & 0 & $3.22 \pm 3.54(3.13)$ & 12.50 & Figure 2b \\
\cline { 2 - 6 } & Unfenced & 32 & 0 & $5.87 \pm 6.77(3.13)$ & 31.25 & \\
\hline
\end{tabular}

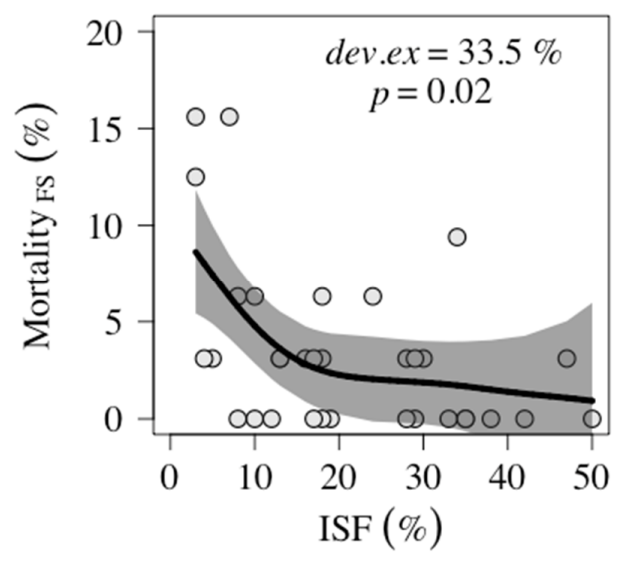

(a)

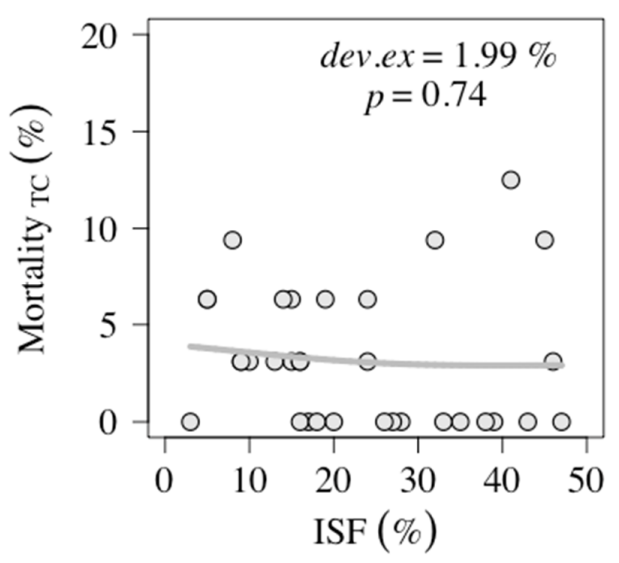

(b)

Figure 2. Mortality of (a) F. sylvatica seedlings (FS) and (b) T. cordata seedlings (TC) on fenced plots $(n=33)$ in association with light, measured as indirect site factor (ISF). Significant trends $(p<0.05)$ in association with light are shown as a black line, non-significant trends as a grey line. Shaded grey area shows the $95 \%$ confidence interval. Both explained deviance and $p$-values were extracted from the generalized additive model (GAM)-models.

\subsection{Seedling Biomass}

\subsubsection{Biomass before and after Growing Season}

Due to browsing damage on a side shoot, one F. sylvatica seedling had to be excluded in this analysis. The seedlings' dry mass, calculated as total dry mass (TDM), aboveground biomass (AGB), and root mass (RM), were compared before and after the first growing season for both tree species. Changes could not be detected, neither in F. sylvatica (Kruskal-Wallis-Test: $0.07<p<0.11$ ) nor in T. cordata $(0.17<p<0.24)$ (Table 2$)$. 
Table 2. Seedlings' biomass before and after the growing season 2017. Total dry mass (TDM), aboveground biomass (AGB), and belowground biomass (RM) of $F$. sylvatica and T. cordata before (nursery) and after the first vegetation period (harvest) in $\mathrm{g}$. The leaf weights from harvested seedlings were excluded from TDM and AGB. $n^{1}$ is the sample size of seedlings from the nursery, $n^{2}$ is the sample size of the harvested plants. Shown are minimum (Min), mean and standard deviation (SD), median, and maximum (Max) values.

\begin{tabular}{|c|c|c|c|c|c|c|c|c|c|c|c|}
\hline \multirow{2}{*}{ Species } & \multicolumn{5}{|c|}{ Nursery } & \multicolumn{5}{|c|}{ Harvest } & \multirow{2}{*}{$p$ (Kruskal) } \\
\hline & Sample & Unit & $\mathrm{n}^{1}$ & Min & Mean \pm SD (Median) & Max & $\mathrm{n}^{2}$ & Min & Mean \pm SD (Median) & Max & \\
\hline \multirow{3}{*}{ F. sylvatica } & TDM & $\mathrm{g}$ & 30 & 13.39 & $26.68 \pm 11.02(25.29)$ & 59.63 & 98 & 12.42 & $31.33 \pm 12.95$ (29.16) & 70.59 & 0.09 \\
\hline & AGB & $\mathrm{g}$ & 30 & 5.93 & $12.62 \pm 5.97(11.28)$ & 31.38 & 98 & 6.20 & $14.47 \pm 6.34(13.09)$ & 35.91 & 0.11 \\
\hline & $\mathrm{RM}$ & $\mathrm{g}$ & 30 & 6.60 & $14.06 \pm 5.46(13.80)$ & 28.26 & 98 & 6.09 & $16.86 \pm 7.21(15.18)$ & 39.78 & 0.07 \\
\hline \multirow{3}{*}{ T. cordata } & $\mathrm{TDM}$ & $\mathrm{g}$ & 28 & 3.17 & $7.74 \pm 4.12(7.35)$ & 19.08 & 99 & 1.46 & $9.14 \pm 4.84(7.68)$ & 24.51 & 0.20 \\
\hline & AGB & $\mathrm{g}$ & 28 & 1.52 & $3.46 \pm 1.67(2.94)$ & 8.65 & 99 & 0.86 & $3.93 \pm 1.89(3.59)$ & 9.38 & 0.24 \\
\hline & $\mathrm{RM}$ & $\mathrm{g}$ & 28 & 1.05 & $4.28 \pm 2.59(3.82)$ & 11.27 & 99 & 0.58 & $5.21 \pm 3.13(4.44)$ & 15.27 & 0.17 \\
\hline
\end{tabular}




\subsubsection{Response in Mass Fractions along the Light Gradient}

The three tested stands (b2, c2, c3) did not reveal a significant difference on the mass fractions (MF) of leaves (LMF), branches (BMF), stem (SMF), and roots (RMF) neither for F. sylvatica $(0.14<p<0.70)$ nor $T$. cordata $(p=0.06<p<0.65)$. The treatment of $P$. serotina itself also showed no significant difference on the compartment mass fractions for F. sylvatica $(0.82<p<0.94)$ or T. cordata $(0.26<p<0.55)$. Table S2 (supplementary material) contains the complete seedlings dataset on mass fractions.

The LMF of $F$. sylvatica seedlings was the only mass fraction that showed a significant trend along the light gradient (Table 3). The LMF increased by $0.04 \%$ with $1 \%$ light availability, measured as ISF (Figure 3). The three other mass fractions in F. sylvatica (BMF, SMF, RMF) and also AGB did not respond along the gradient $(0.127<p<0.310)$ (Table 3). AGB and none of the mass fractions of $T$. cordata showed a significant trend along the light gradient $(0.127<p<0.841)$ (Table 3).

Table 3. Results from generalized linear models (GLM) for seedlings growth response analysis in regard to light (model: $\mathrm{y} \sim \mathrm{ISF}$ ). Results for F. sylvatica and T. cordata with light (ISF) as influencing factor on aboveground biomass (AGB), leaf mass fraction (LMF), branch mass fraction (BMF), stem mass fraction (SMF), root mass fraction (RMF), and specific leaf area (SLA).

\begin{tabular}{|c|c|c|c|c|c|c|c|}
\hline Species & $\begin{array}{c}\text { Response } \\
\text { Variable }\end{array}$ & Slope & $p$-Value & Intercept & $\begin{array}{c}\text { Model } \\
\text { Equation }\end{array}$ & $R^{2}$ & $\begin{array}{c}\text { Ass. } \\
\text { Figure }\end{array}$ \\
\hline \multirow{6}{*}{ F. sylvatica } & AGB & 0.08 & 0.194 & 15.86 & $0.08 x+15.86$ & 0.02 & \\
\hline & LMF & 0.04 & 0.016 & 7.94 & $0.04 x+7.94$ & 0.06 & Figure 3 \\
\hline & BMF & -0.03 & 0.310 & 11.64 & $-0.03+11.64$ & 0.01 & \\
\hline & SMF & -0.06 & 0.127 & 32.51 & $-0.06+32.51$ & 0.02 & \\
\hline & RMF & 0.05 & 0.205 & 47.91 & $0.05+47.91$ & 0.02 & \\
\hline & SLA & -0.87 & $>0.001$ & 256.14 & $-0.87+256.14$ & 0.13 & Figure 4 \\
\hline \multirow{6}{*}{ T. cordata } & AGB & 0.03 & 0.127 & 4.29 & $0.03+4.29$ & 0.02 & \\
\hline & LMF & 0.03 & 0.226 & 9.25 & $0.03+9.25$ & 0.02 & \\
\hline & BMF & -0.005 & 0.839 & 3.55 & $-0.005+3.55$ & $>0.001$ & \\
\hline & SMF & -0.03 & 0.589 & 37.83 & $-0.03+37.83$ & 0.003 & \\
\hline & RMF & 0.01 & 0.841 & 49.37 & $0.01+49.37$ & $>0.001$ & \\
\hline & SLA & -2.01 & $>0.001$ & 343.87 & $-2.01+343.87$ & 0.21 & Figure 4 \\
\hline
\end{tabular}

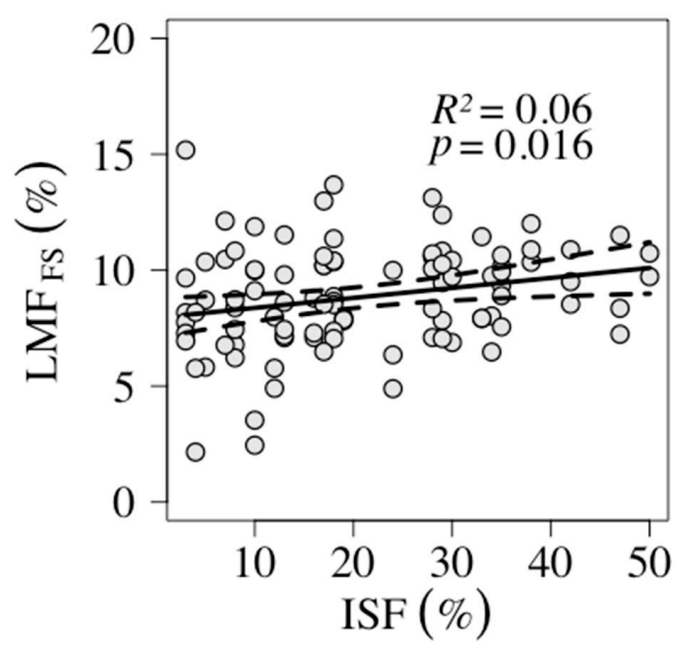

Figure 3. Leaf mass fraction (LMF) of F. sylvatica seedlings (FS) from fenced plots in association with indirect site factor (ISF). The sample-size was $n=98$. Black solid line shows the trend and the shaded grey area shows the $95 \%$ confidence interval. $R^{2}$ and the $p$-value were extracted from the GLM (generalized linear model). 


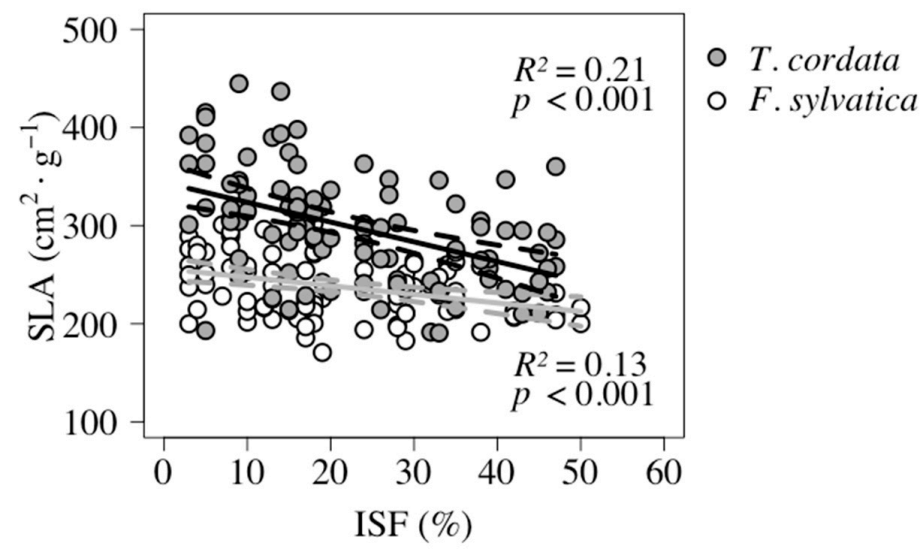

Figure 4. Specific leaf area (SLA) in association with light, measured as indirect site factor (ISF). Sample size for $F$. sylvatica was $n=96$ and for T. $\operatorname{cordata} n=99$. The trends were significant for both tree species $(p<0.001)$ and are shown as solid lines (black shows the trend for T. cordata and grey shows the trend for F. sylvatica). Dashed lines show the 95\% confidence intervals.

\subsection{Specific Leaf Area}

Three harvested F. sylvatica seedlings with only dried-out leaves had to be excluded in this analysis. The mean leaf area (LA) did not respond along the light gradient (F. sylvatica $p=0.936$; . cordata $p=$ 0.658). The specific leaf area (SLA) in F. sylvatica leaves ranged from 170.7 to $307.0 \mathrm{~cm}^{2} \mathrm{~g}^{-1}$, which was on average less than for T. cordata leaves ranging from 190.6 to $444.8 \mathrm{~cm}^{2} \mathrm{~g}^{-1}$. SLA was on average $25.3 \%$ greater in leaves of $T$. cordata $(p<0.001)$ (Table 4$)$.

Table 4. Number of scanned leaves and determined specific leaf area per subsample. Number of scanned leaves and SLA in F. sylvatica and T. cordata after the vegetation season 2017. Shown are sample size (N), minimum (Min), mean and standard deviation (SD), median and maximum (Max) values.

\begin{tabular}{cccccccc}
\hline \multirow{2}{*}{ Species } & $\mathbf{N}$ & \multicolumn{3}{c}{ Scanned Leaves per Subsample $(\mathbf{n})$} & \multicolumn{3}{c}{ SLA $\left(\mathbf{c m}^{\mathbf{2}} \mathbf{g}^{-\mathbf{1}}\right)$} \\
\cline { 3 - 8 } & & Min & $\begin{array}{c}\text { Mean } \pm \text { SD } \\
\text { (Median) }\end{array}$ & Max & Min & $\begin{array}{c}\text { Mean } \pm \text { SD } \\
\text { (Median) }\end{array}$ & Max \\
\hline F. sylvatica & 96 & 6 & $19.8 \pm 1.8(20)$ & 22 & 170.7 & $\begin{array}{c}237.6 \pm 31.4 \\
(232.4)\end{array}$ & 307.0 \\
\hline T. cordata & 99 & 3 & $9.6 \pm 1.6(10)$ & 13 & 190.6 & $\begin{array}{c}297.7 \pm 56.8 \\
(298.0)\end{array}$ & 444.8 \\
\hline
\end{tabular}

SLA was negatively correlated with light in both tree species, as SLA decreased with an increase in light (both species: $p<0.001$ ) (Table 3). A greater proportion of the variance in SLA was explained by light in leaves of T. cordata $\left(R^{2}=0.21\right)$ in comparison to leaves of $F$. sylvatica $\left(R^{2}=0.13\right)$ (Table 3).

A comparison of the slopes in both models revealed significant differences $(p=0.02)$ for the two species along the gradient. The response of leaves to increased light was stronger for leaves of $T$. cordata, indicating higher morphological plasticity than for F. sylvatica (Figure 4).

\section{Discussion}

\subsection{Mortality}

\subsubsection{Higher Mortality outside the Fence Due to Herbivory}

Mortality after the first vegetation season was marginal (Figure 1). Therefore, the seedlings' initial survival was considered a successful start of the experiment. The low losses were potentially also due to the hydrogel treatment applied before planting which may have functioned as a mechanical 
protection for the fine roots [31]. The finding that more seedlings died outside the fence (Figure 1) can be explained by grazing mammals, whose browsing on seedlings commonly result in the loss of the leader shoot [32]. This loss is closely correlated to seedling mortality if approximately one third of the shoot length is browsed [33]. In the present study seedlings were sometimes browsed down to ground level or were partly missing. During the time this field experiment, grazing species such as roe deer (Capreolus capreolus, L. 1758), red deer (Cervus elaphus, L. 1758) [34], wild boar (Sus scrofa, L. 1758) [35], and European hares (Lepus europaeus, PALLAS 1778) [36] were recorded by cameras directly on the study sites. Browse damage is most intense on seedlings of $1.00-1.30 \mathrm{~m}$ in height [37]. The underplanted seedlings in the stands in Linde ( $\mathrm{min}$. size 0.16 to max. size $1.24 \mathrm{~m}$ ) were therefore especially susceptible to grazing by mammalian herbivores.

\subsubsection{F. sylvatica Mortality Response to Light}

Shade tolerance is a plant's ability to persist in the understory at low light levels [38]. F. sylvatica in particular is considered to be one of, if not the most, shade tolerant species among important deciduous tree species in Germany [30,39]. F. sylvatica seedlings in this survey, however, responded to low light levels with the highest amount mortality in this experiment, but as light increased mortality decreased (Figure 2). This outcome is in line with other findings [40-43]. The ability of $F$. sylvatica to survive under somewhat dense P. serotina shrub layers with low light levels in the dense understory was expected [26-28]. That the mortality of $T$. cordata did not respond along the light gradient was surprising. One growing season seems to be too short to detect this effect as the seedlings are exposed to totally different biotic (e.g., competition, parasites, grazing) and abiotic factors (e.g., climate, soil, light, water, nutrients) in the forest compared to the nursery. This outcome may have been caused by other factors than the influence of light such as soil composition or soil properties, since every tree species has its own optimum in terms of soil acidity or soil aridity for instance [30,39]. Additionally, an influence by the strong competitor P. serotina is conceivable. Competition can arise when resources (here: light) become more available [44] so as P. serotina could have had reacted to the presence of the underplanted seedlings.

\subsection{Seedling Biomass}

\subsubsection{No Detectable Biomass Increases after the Growing Season}

The theory of plants' optimal biomass allocation, known as the 'functional equilibrium hypotheses' [45,46] or 'balanced growth hypothesis' [47] suggests that plants increase allocation to organs that best access limiting resources. For example, allocation to leaves is increased when plants are limited by light $[30,48]$. In high light environments, plants invest more biomass to the roots $[49,50]$ by increasing transpiration [51]. Therefore, plants react under changed light regimes with different biomass allocation strategies depending on which environmental factors change [29,48].

In this survey, the comparisons of the seedling biomass (TDM, AGB, RM) before and after the vegetation period revealed no significant changes in either trees species (Table 2). This may have been due to the destructive harvest after only one vegetation season and an acclimation process that had just started. Acclimation by seedlings to changed environmental factors has been documented in other studies $[49,52,53]$. Since none of our tested dry masses showed biomass increases (Table 2), the degree of acclimation of the small trees in this survey could not be clarified. Indeed, seedlings sprouts in the spring from the stock obtained from the previous year, but in our case the planting shock seemed to have strongly influenced the seedlings as they did not grow significantly during the vegetation period 2017. The seedlings' growth performance did not reveal significant differences in terms of the mechanical treatments applied to $P$. serotina.

However, the high survival rates of both F. sylvatica and T. cordata, in between the established population of $P$. serotina point towards the potential of underplanting. This could be a promising silvicultural alternative to outcompete the invasive species in the long run [26-28]. A retreatment of 
regrown P. serotina sprouts (following the initial mechanical treatments) after two to four vegetation periods would most likely strongly increase the probability of this approach to work. However, the impact of browsing should not be underestimated. If game populations are high, fencing might be necessary because native species are preferably browsed on. In addition to the expansive mechanical treatments, this would increase the costs strongly.

\subsubsection{Unexpected Response in F. sylvatica LMF}

Changes in allocation depending on changed light conditions were shown in other studies (in leaves $[40,49,54,55]$, in branches and stems [55,56], and in roots $[40,49,50])$.

Unexpectedly, F. sylvatica LMF decreased in low light conditions in this survey (Figure 3, Table 3). The effect size was minimal. This result also contradicts findings from other studies that support the theory of allocation, namely that LMF increases with shade in shade tolerant species $[40,49,55]$. Nevertheless, another study [41] also found an unexpected decrease in F. sylvatica LMF with shade. The authors there considered a fungal disease responsible for their results.

\subsection{Shade Tolerant Species-Specific Reaction in Leaves}

Results of SLA measurements in this survey confirmed findings of others that SLA decreases with increasing light availability [40,41,49,57]. The mean leaf area did not change along the light gradient, indicating that changes in SLA could be attributed to morphological changes in lamina thickness [49,58,59] and as morphological reactions of leaves to varying light conditions [29]. We found on average smaller SLA in F. sylvatica as compared to T. cordata along the entire gradient. Our model for $T$. cordata suggests a more sensitive reaction to changes in light availability in juvenile $T$. cordata as compared to juvenile F. sylvatica (Figure 4). Both species reacted to changed light availability resulting from mechanical treatments to $P$. serotina, which suggests an ongoing acclimation to the environmental conditions in the forest of Linde.

\section{Materials and Methods}

\subsection{Study Area}

The study area is located in Linde and belongs to the Zwillenberg-Tietz Foundation. Linde is located in eastern Germany (52 $33^{\prime} 4.337^{\prime \prime} \mathrm{N}, 12^{\circ} 40^{\prime} 55.08^{\prime \prime} \mathrm{E}$ ) inside the federal state of Brandenburg $50 \mathrm{~km}$ from the German capital Berlin (Figure 5a). The region around the study site is dominated by managed forests and agricultural land. Geologically characterized by flat-wave ground moraine plates and dune fields, the forest sites are rather nutrient poor. The climate of the region is classified as temperate with high temperatures in summer and moderately cold temperatures in winter. The annual average temperature is about $9^{\circ} \mathrm{C}$. Most rainfall occurs in summer during the vegetation period, with an annual precipitation of 520-572 $\mathrm{mm}$ [60]. The annual average temperature in 2017 was about $10^{\circ} \mathrm{C}$ in the federal state of Brandenburg, which was $1.1^{\circ} \mathrm{C}$ warmer, compared to the current normal periods from 1981 to 2010 (German Meteorological Service, Deutscher Wetterdienst). The precipitation in 2017 was consistently measured in 10-min intervals in a nearby meteorological station and resulted in an annual precipitation of $432.8 \mathrm{~mm}$ during the growing season 2017.

The study sites are at an altitude of about 63-86 m above sea level. The forests are dominated by Scots pine (P. sylvestris L.), but Norway spruce (Picea abies (L.) H.Karst.) and European larch (Larix decidua MiLl.) also occur. Some deciduous trees, such as red oak, (Quercus rubra L.), small-leaved lime (Tilia cordata Mill.), a few individuals of chestnut (Castanea sp. Mill.), maple (Acer sp. L.), birch (Betula sp. L.), and black locust (Robinia pseudoacacia L.) can also be found. The non-native tree species Prunus serotina has been spreading throughout the region since the early 20th century.

The study sites were placed in relatively pure and even-aged pine stands with a $P$. serotina understory (b2, c2, c3; Figure 5b). The stands differ by thinning regime. Stand b2 was last thinned in March 2017, prior to the planting activities. Stand c3 was unthinned and stand c2 was thinned 
before 2006. The abundance of $P$. serotina varied slightly throughout the stands. The stand situations encountered in Linde are representative of many pine forests in eastern Germany, where P. serotina grows invasively (Figure 5c).

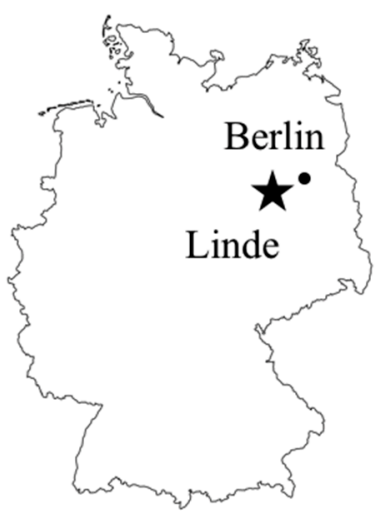

(a)

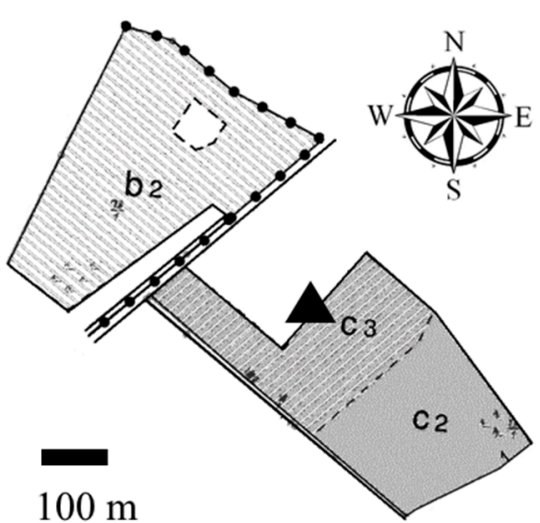

(b)

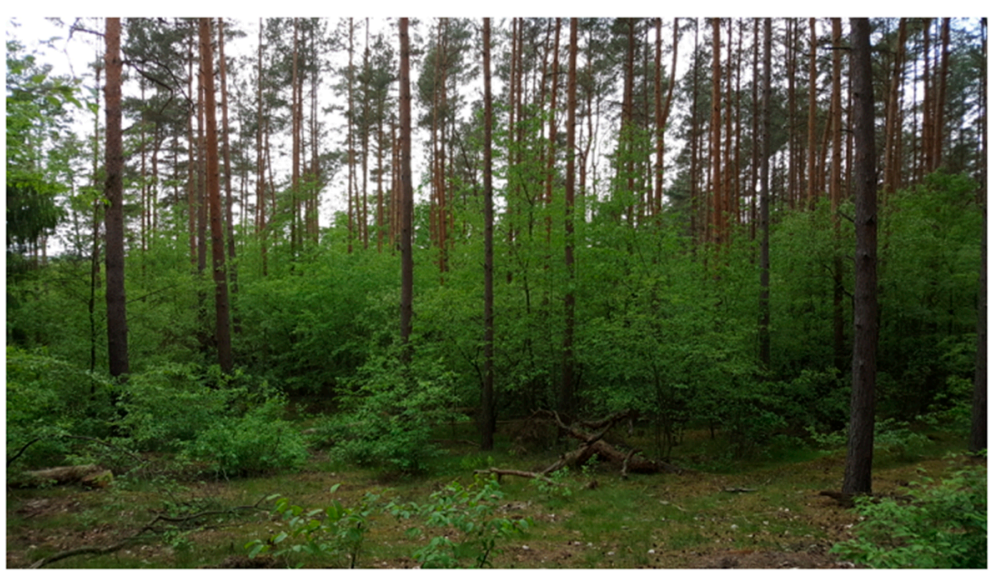

(c)

Figure 5. Study sites. (a) Location of Linde (star icon) as part of the federal state of Brandenburg. (b) Georeferenced forest map section with three study sites (b2, c3, c2). (c) Characteristic situation in the study area with established dense shrubby layers of Prunus serotina in the understory (date: 23.05.2017; place: stand c3, photo-location was labeled in Figure 5b).

\subsection{Study Design}

The study design was based on a block design. One block contained 18 individual $100 \mathrm{~m}^{2}$ plots with randomized treatments. The plots were arranged with $5 \mathrm{~m}$ spacing to one another and a minimum distance of $2 \mathrm{~m}$ to existing skidding trails. Eleven block replicates were established for a total of 197 plots (one plot was excluded), of which 90 plots were in b2, 57 in c2, and 50 in c3 (Figure 5b). The number of plots within the three stands differed due to the size of the stands. Each plot consisted of (1) a mechanical treatment applied to the P. serotina trees (felling or girdling), or control (without mechanical treatment), and (2) one out of two underplanted native tree species, or control (without underplanting). These plot-combinations existed fenced and unfenced. The protected plots were fenced with $1.80 \mathrm{~m}$ high game-proof wire to exclude grazing mammals, mainly ungulates. The plots were randomly spaced within the blocks (Figure 6a).

High shade tolerance in juvenile stages was required for the successful establishment of species under P. serotina [23-28]. Highly shade tolerant tree species native to Germany are Fagus sylvatica 
and T. cordata $[30,37,39,56]$, therefore these two species were chosen. As planting material, 2-year-old wildstock seedlings of F. sylvatica and T. cordata were used. F. sylvatica seedlings had an initial biomass of $26.68 \pm 11.02 \mathrm{~g}$. The average biomass of $T$. cordata was $7.74 \pm 4.12 \mathrm{~g}$. The provenance of the planting material was Mark-Lusatia flatland for F. sylvatica (81005) and central and east German low and highlands for T. cordata (82303) [61]. Planting was conducted over 3 days in spring 2017. A total of 4189 seedlings (2109 F. sylvatica and 2080 T. cordata) were planted using a planting auger. Before the seedlings were planted, they were dipped into a hydrogel solution (GEFA Wurzelschutzgel) to improve their water storage and absorbance capabilities and to improve their overall survival rates [31]. Plant spacing was $2 \times 1 \mathrm{~m}\left(5000\right.$ plants $\left.\cdot \mathrm{ha}^{-1}\right)$, with 32 plants per plot (eight individuals $\times$ four rows, Figure 6b).

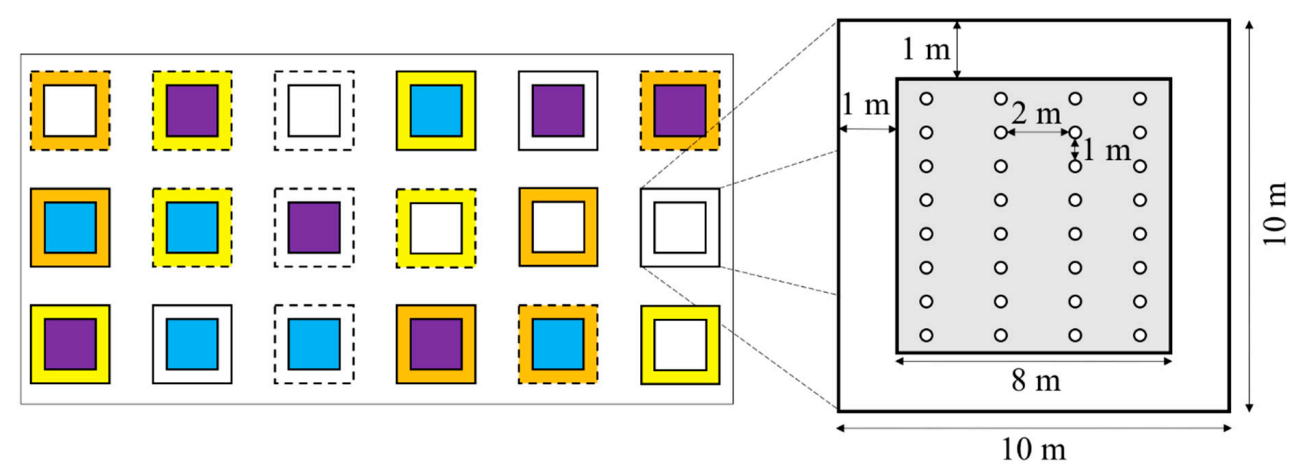

(a)

(b)

Figure 6. Experimental study design. (a) Exemplary presentation of a randomized block $(n=11)$ with 18 different plot variations. Outer square colors mark treatments applied to P. serotina: felling (yellow), girdling (orange), control (white); inner square colors mark underplanted tree species: F. sylvatica (blue), T. cordata (purple), no underplanting (control, white); Outer line type indicates protection: solid line (fenced), dashed line (unfenced). All plots were placed at $5 \mathrm{~m}$ distance from skidding trails. (b) Planting scheme on each $100 \mathrm{~m}^{2}$ plot. Fenced plots had $1 \mathrm{~m}$ distance between seedlings and fence. Plant spacing was $2 \times 1 \mathrm{~m}$, resembling a density of 5000 plant ha $^{-1}$.

As mechanical treatments to control P. serotina, felling and girdling were applied. Before the treatments were applied to the trees, their dbh (diameter in breast height) was measured using a calliper. This study focuses on trees with a diameter in breast height $\geq 5 \mathrm{~cm}$. Smaller trees $(\mathrm{dbh}<5 \mathrm{~cm})$ were counted and mechanically treated in the same way. On average, $12.53 \pm 11.94$ P. serotina trees with a dbh $\geq 5 \mathrm{~cm}$ grew on each plot. A total of $403 P$. serotina trees with a dbh $\geq 5 \mathrm{~cm}$ were felled and removed from the plots in March and April 2017. Girdling work was done by completely removing the bark and cambium on a $15 \mathrm{~cm}$ wide stem circumference section beneath the lowest living branch using a chain girdler. The girdling treatment was applied in August 2017, assuming this would have the greatest detrimental effect to suppress greater sprout responses at the end of the vegetation period [62]. A total of 363 P. serotina trees with a dbh $\geq 5 \mathrm{~cm}$ were girdled.

\subsection{Field Data Collection}

\subsubsection{Seedling Delivery}

We received 4247 2-year-old wildstock seedlings (2139 F. sylvatica and 2108 T. cordata) from the nursery and removed 58 before planting as a basic data set (nursery plants). These seedlings (30 F. sylvatica and 28 T. cordata) were randomly chosen from the delivered plants to record the initial conditions and mass fractions for later comparisons. Overall, 4189 seedlings (2109 F. sylvatica and 2080 T. cordata) were planted of which one F. sylvatica and 18 T. cordata seedlings died directly after planting activities. Therefore, the experiment started with 4170 seedlings (2108 F. sylvatica and 2062 T. cordata). 


\subsubsection{Seedling Mortality}

The vitality of each seedling was recorded at the end of the vegetation period. Plants were considered as dead if they were either totally dried-out, had been browsed down to the ground, or were simply missing. Mortality was calculated on each plot as the ratio between dead and planted seedlings.

\subsubsection{Seedling Harvest}

Three randomly selected seedlings were destructively harvested (above- and belowground biomass, maximum two seedlings per planting row) on each plot at the end of the growing season 2017, before the seedlings shed their leaves. This resulted in a total of 393 harvested seedlings, 198 F. sylvatica and 195 T. cordata (three harvested seedlings on 12 underplanted plots in 11 replicates minus three seedlings, because one plot was excluded).

\subsubsection{Light Measurements}

All light measurements were carried out during the second week of July 2017. A single measurement was recorded on each plot using a hemispherical photography device equipped with a fisheye-lens (Behling, Solariscope SOL300). Measurements were conducted at $2 \mathrm{~m}$ above ground. In this study the ISF (indirect site factor) was used to classify the light environment on each plot. ISF is defined as proportion of diffuse radiation to open field condition, that reaches the measured point (here: per plot).

\subsection{Lab Data Collection}

Like the 58 removed nursery plants before, all 393 harvested seedlings were partitioned into leaves, branches, stems, and roots. These compartments were dried for 3 days in a temperature-controlled oven at $70^{\circ} \mathrm{C}$ and weighed. Seedlings total dry mass (TDM) was the summed weight of all components: leaf mass (LM), branch mass (BM), stem mass (SM), and root mass (RM) (Equation (1)).

$$
\mathrm{TDM}[\mathrm{g}]=\mathrm{LM}[\mathrm{g}]+\mathrm{BM}[\mathrm{g}]+\mathrm{SM}[\mathrm{g}]+\mathrm{RM}[\mathrm{g}]
$$

Seedling aboveground biomass (AGB) was the sum of leaf mass (LM), branch mass (BM), and stem mass (SM) (Equation (2)).

$$
\mathrm{AGB}[\mathrm{g}]=\mathrm{LM}[\mathrm{g}]+\mathrm{BM}[\mathrm{g}]+\mathrm{SM}[\mathrm{g}]
$$

From the weight of the compartments, mass fractions could then be derived for every seedling. These were leaf mass fraction (LMF), branch mass fraction (BMF), stem mass fraction (SMF), and root mass fraction (RMF) (Equation (3)).

$$
\text { compartment mass fraction }[\%]=\frac{\text { compartment dry mass }[\mathrm{g}]}{\mathrm{TDM}[\mathrm{g}]} \times 100[\%]
$$

Subsamples of 20 fresh leaves of $F$. sylvatica and 10 fresh leaves of $T$. cordata were randomly selected out of a collection tank after all leaves had been fully removed from each harvested seedling. The subsamples were scanned to determine mean leaf area (LA, Equation (4)) and specific leaf area (SLA, Equation (5)) for each harvested seedling. The sample size for both species differed since T. cordata seedlings have less leaves compared to F. sylvatica seedlings. The leaf area was determined using the software WinFOLIA (Regent Instruments Inc.).

$$
\begin{gathered}
\text { LA }\left[\mathrm{cm}^{2}\right]=\frac{\text { leaf area }}{\text { subsample }\left[\mathrm{cm}^{2}\right]} \\
\text { number of leaves } \text { subsample }_{\text {s] }}[\mathrm{n} \\
\text { SLA }\left[\mathrm{cm}^{2} \mathrm{~g}^{-1}\right]=\frac{\text { leaf area } \text { subsample }_{\text {sem }}\left[\mathrm{cm}^{2}\right]}{\text { leaf dry mass }} \text { subsample }[\mathrm{g}]
\end{gathered}
$$




\subsection{Data Analysis and Modelling}

Statistical data analyses and graphs were processed using the statistical free software environment RStudio for R (Version 1.1.383 for Mac) [63]. Significance-level was $p<0.05$.

Normality of distribution was checked using the Shapiro-Wilk test. Distribution was verified additionally in quantile-quantile-plots or frequency-plots. Homoscedasticity within groups (fencing, tree-species) was tested with Bartlett's test. The non-parametric Kruskal-Wallis test (one-way ANOVA of ranks) or ANOVA were used to analyze differences in groups depending on data distribution and homoscedasticity.

Correlations between non-normal distributed data were calculated by using the non-parametric method of Kendall's rank correlation coefficient tau $(\tau)$ to test for relationships between response variables (mortality rates, mass fractions, specific leaf area) and explanatory variables (ISF). Calculated means were compared using the independent two-sample $t$-test or Welch's test, depending whether or not the variances for the tested groups were equal. Chi-squared test was performed to test attributes (alive or dead seedlings) for independence within groups (fencing, species).

For modelling the mass fractions along the light gradient, generalized linear models (GLM) were used with indirect site factor (ISF) as independent variable (Equation (6)), where $y$ was the vector of the dependent variable, $\mathrm{x}$ the predictors matrix, $\alpha$ the vector of weighed predictors and $\varepsilon$ the vector of residuals.

$$
\mathrm{y}=\mathrm{x}+\varepsilon
$$

The coefficient of determination $\left(R^{2}\right)$ is defined as the proportion of the variance in the dependent variable (TDM, AGB, compartment mass fractions, SLA) which can be predicted from the independent variable (light, measured as ISF) (Equation (7)). The coefficient of determination was used to evaluate the goodness of fit of the calculated GLMs.

$$
R^{2}=1-\frac{\text { residual sum of squares }}{\text { total sum of squares }}
$$

Generalized additive models (GAM) (Equation (8)) were used to estimate mortality along the light gradient (ISF), in order to determine an unbiased detection of trends in the data [64]. Mortality was modelled as function of available light, $f$ as effect-specific regression spline function of the explanatory variable (ISF), $\alpha$ as intercept, and $\varepsilon$ the error term assumed to be normally distributed with a mean value of zero and with finite variance (R-package 'mgcv') [65].

$$
\mathrm{y}=\alpha_{\mathrm{i}}+f_{i}(\mathrm{x})+\varepsilon
$$

\section{Conclusions}

Since the results of this study are based on just 1 year of observation the following conclusions need to be checked in the near future. Surprisingly, we did not find higher mortality under low light conditions in T. cordata than in F. sylvatica, which is considered to be more shade tolerant than T. cordata. However, we could show that $F$. sylvatica and T. cordata show a relatively low mortality if underplanted in Scots pine stands that had been invaded by P. serotina. This finding shows the potential of this approach to grant seedlings access to light by using mechanical control against $P$. serotina. Retreatments of regrown sprout might be necessary to keep up the seedling's vitality. Fencing increases costs strongly. With one exception no changes in biomass allocation with decreasing light availability could be observed after one growing season. However, stronger morphological responses to the changed light environments as result of the treatments in both F. sylvatica and T. cordata can be expected in the up-coming years, as a result of a possibly delayed response after transplanting. The different light regimes on the plots will then most likely cause more noticeable differences in biomass allocation and growth, which will allow to identify best planting conditions. Therefore, the experiment in Linde is pursued and more data will continue to improve the recommendations that can be derived from this study for foresters dealing with the invasive tree species P. serotina. 
Supplementary Materials: The following are available online at http://www.mdpi.com/2223-7747/9/6/677/s1, Table S1: Seedling mortality, Table S2: Seedling data, Table S3: Abbreviations, Figures 1-6.

Author Contributions: Conceptualization, P.A.; Formal analysis, S.L.H.; Funding acquisition, P.A.; Investigation, S.L.H. and P.A.; Methodology, S.L.H. and P.A.; Project administration, S.L.H. and P.A.; Supervision, P.A.; Visualization, S.L.H. and P.A.; Writing-original draft S.L.H.; Writing-review \& editing, S.L.H. and P.A. All authors have read and agreed to the published version of the manuscript.

Funding: This research was funded by Zwillenberg-Tietz-Stiftung.

Acknowledgments: Gratitude is owed to the Zwillenberg-Tietz foundation for funding this study and giving us access to their stands for setting up this field experiment. We are grateful for receiving access to stands together with Martin Hasselbach to find suitable stands and also his support regarding information about the stands. We thank Marcus Wicke for his help in the field. We would also like to thank Ulrike Westphal for supporting fieldwork, data acquisitions in the field, performing the lab work, and her constructive comments regarding plot measuring and tree labeling. Many thanks go to Michael Unger and Ray Wollenzien for felling and removing the trees in stand b2 in only one day and Steffi Heinrichs for her data acquisition concerning the vegetation. Thanks are also due to our student assistants for their help with setting up the field experiment, labeling, data acquisition, felling and clearing plots and performing lab work. We would like to thank Christian Ammer for guidance and helpful comments on an earlier draft of this manuscript. We further acknowledge the linguistic corrections made by Kathleen Regan (USA). We would like to thank the reviewers for their helpful comments towards improving our manuscript.

Conflicts of Interest: The authors declare no conflict of interest. The funders had no role in the design of the study; in the collection, analyses, or interpretation of data; in the writing of the manuscript, or in the decision to publish the results.

\section{References}

1. Mack, R.N.; Simberloff, D.; Lonsdale, W.M.; Evans, H.; Clout, M.; Bazzaz, F.A. Biotic Invasions: Causes, Epidemiology, Global Consequences, and Control. Ecol. Appl. 2000, 10, 689-710. [CrossRef]

2. Ehrenfeld, J.G. Effects of Exotic Plant Invasions on Soil Nutrient Cycling Processes. Ecosystems 2003, 6, 503-523. [CrossRef]

3. Starfinger, U. Population Biology of an Invading Tree Species-Prunus serotina. In Species Conservation: A population-Biological Approach Advances in Life Sciences; Seitz, A., Loeschke, V., Eds.; Birkhäuser-Verlag Basel: Basel, Switzerland, 1991; pp. 171-184.

4. Fowell, H.A. Silvics of Forest Trees of the United States; No. 271. US Department of Agriculture, Forest Service: Washington, DC, USA, 1965.

5. Marquis, D.A. Prunus serotina Ehrh. Black Cherry. Silv. N. Am. 1990, 2, 594-604.

6. Hough, A.F. Preliminary recommendations for the management of black cherry on the northern Allegheny Plateau. J. Forest. 1953, 51, 184-188.

7. Wein, K. Die erste Einführung nordamerikanischer Gehölze in Europa: Teil 1. Mitt. Dtsch. Dendrol. Ges. 1930, 42, 137-163.

8. Wein, K. Die erste Einführung nordamerikanischer Gehölze in Europa. Teil 2. Mitt. Dtsch. Dendrol. Ges. 1931, 43, 95-154.

9. Starfinger, U. Die Einbürgerung der Spätblühenden Traubenkirsche (Prunus serotina Ehrh.) in Mitteleuropa. Ph.D. Thesis, Technical University Berlin, Berlin, Germany, 1990.

10. Starfinger, U.; Kowarik, I.; Rode, M.; Schepker, H. From desirable ornamental plant to pest to accepted addition to the flora?-The perception of an alien tree species through the centuries. Biol. Invasions 2003, 5 , 323-335. [CrossRef]

11. Sinner, H. Prunus serotina, die spätblühende Traubenkirsche als Waldbaum. Mitt. Dtsch. Dendrol. Ges. 1926, 164-184.

12. Kowarik, I. Biologische Invasionen. Neophyten und Neozoen in Mitteleuropa, 2; Auflage; Ulmer Verlag: Stuttgart, Germany, 2010.

13. Leclercq, W.L. Dennenmoorder en Prunus serotina. Ned. Bosb. 1960, 32, 74-75.

14. Starfinger, U. Über Agriophyten: Das Beispiel Prunus serotina. Verh. Berl. Bot. Ver. 1990, 8, 179-188.

15. Klotz, S. Prunus serotina Ehrh., black cherry (Rosaceae, Magnoliophyta). In Handbook of Alien Species in Europe; Drake, J.A., Ed.; Springer: Dordrecht, The Netherlands, 2009.

16. Brehm, K. Erfahrungen mit der Bekämpfung der Spätblühenden Traubenkirsche (Prunus serotina) in Schleswig-Holstein in den Jahren 1977 bis 2004. Schriftenreihe des LANU SH-Natur 2004, 10, 66-78. 
17. Bundesministerium für Umwelt, Naturschutz und Reaktorsicherheit. Ökonomische Folgen der Ausbreitung von Neobiota; Bundesministerium für Umwelt, Naturschutz und Reaktorsicherheit: Berlin, Germany, 2003; Available online: http://www.umweltbundesamt.de (accessed on 3 July 2019).

18. Petersen, R.; Annighöfer, P.; Spellmann, H.; Leder, B. Spätblühende Traubenlkirsche (Prunus serotina Ehrh.). In Potenziale und Risiken Eingeführter Baumarten: Baumartenportraits mit Naturschutzfachlicher Bewertung; Vor, T., Spellmann, H., Bolte, A., Ammer, C., Eds.; Univ.-Verl. Göttingen: Göttingen, Germany, 2015; pp. 167-186, ISBN 9783863952402.

19. Spaeth, I.; Balder, H.; Kilz, E. Das Problem mit der Spätblühenden Traubenkirsche in den Berliner Forsten. Allg. Forst Jagdzeitschrift 1994, 11, 234-236.

20. Closset-Kopp, D.; Chabrerie, O.; Valentin, B.; Delachapelle, H.; Decocq, G. When Oskar meets Alice: Does a lack of trade-off in $r / K$-strategies make Prunus serotina a successful invader of European forests? For. Ecol. Manag. 2007, 247, 120-130. [CrossRef]

21. Annighöfer, P.; Schall, P.; Kawaletz, H.; Mölder, I.; Terwei, A.; Zerbe, S.; Ammer, C. Vegetative growth response of black cherry (Prunus serotina) to different mechanical control methods in a biosphere reserve. Can. J. For. Res. 2012, 42, 2037-2051. [CrossRef]

22. Auclair, A.N. Sprouting Response in Prunus serotina Erhr.: Multivariate Analysis of Site, Forest Structure and Growth Rate Relationships. Am. Midl. Nat. 1975, 94, 72-87. [CrossRef]

23. Annighöfer, P.; Kawaletz, H.; Terwei, A.; Mölder, I.; Zerbe, S.; Ammer, C. Managing an invasive tree species-Silvicultural recommendations for black cherry (Prunus serotina Ehrh.): Bewirtschaftung einer invasiven Baumart-Waldbauliche Empfehlungen für die Spätblühende Traubenkirsche (Prunus serotina Ehrh.). Forstarchiv 2015, 86, 139-152.

24. Borrmann, K. Ausbreitung und rationelle Bekämpfung der Spatblühenden Traubenkirsche (Prunus serotina). Soc. Forstwirtsch. 1988, 38, 366-371.

25. Muys, B.; Maddelein, D.; Lust, N. Ecology, Practice and Policy of Black cherry (Prunus serotina Ehrh.) Management in Belgium. Silva Gandav. 1992, 57, 28-45. [CrossRef]

26. Hamm, T.; Huth, F.; Wagner, S. Kiefernforsten renaturieren trotz Spätblühender Traubenkirsche? AFZ-DerWald 2015, 70, 22-25.

27. Hamm, T.; Huth, F.; Wagner, S. Einfluss der Spätblühenden Traubenkirsche (Prunus serotina EHRH.) auf die Verjüngung heimischer Laubbaumarten in Kiefernforsten. Forsch. DBU-Nat. Dyn. Offenland Wald Dtsch. Bundesstiftung Umw. Osnabrück 2017, 2017, 40-46.

28. Petersen, R. Waldbaulicher Umgang mit der Spätblühenden Traubenkirsche. AFZ-DerWald 2015, 70, 18-21.

29. Lambers, H.; Chapin, F.S., III; Pons, T.L. Plant Physiological Ecology, 2nd ed.; Springer: New York, NY, USA, 2008.

30. Matyssek, R.; Fromm, J.; Rennenberg, H.; Roloff, A. Biologie der Bäume: Von der Zelle zur globalen Ebene. 32 Tabellen, 1; Auflage Ulmer; UTB: Stuttgart, Germany, 2010.

31. Thomas, D.S. Hydrogel applied to the root plug of subtropical eucalypt seedlings halves transplant death following planting. For. Ecol. Manag. 2008, 255, 1305-1314. [CrossRef]

32. Gill, R.M.A. A Review of Damage by Mammals in North Temperate Forests: 3. Impact on trees and Forests. Forestry 1992, 65, 363-388. [CrossRef]

33. Rüegg, D.; Nigg, H. Schweizerische Zeitschrift für Forstwesen. Schweiz. Z. Forstwes. 2003, 154, $314-321$. [CrossRef]

34. Gill, R.M.A. A Review of Damage by Mammals in North Temperate Forests: 1. Deer. Forestry 1992, 65, 145-169. [CrossRef]

35. Ammer, C.; Vor, T.; Knoke, T.; Wagner, S. Der Wald-Wild-Konflikt: Analyse und Lösungsansätze vor dem Hintergrund Rechtlicher, Ökologischer und Ökonomischer Zusammenhänge; Universitätsverlag Göttingen: Göttingen, Germany, 2010.

36. Gill, R.M.A. A Review of Damage by Mammals in North Temperate Forests. 2. Small Mammals. Forestry 1992, 65, 281-308. [CrossRef]

37. Bartsch, N.; Röhrig, E. Waldökologie. Einführung für Mitteleuropa; 1. Aufl. 2016; Springer Spektrum: Berlin/Heidelberg, Germany, 2016; ISBN 9783662442678.

38. Vallandares, F.; Niinemets, Ü. Shade tolerance, a key plant feature of complex nature and consequences. Ann. Rev. Ecol. Evol. Sys. 2008, 39, 237-257. [CrossRef] 
39. Ellenberg, H.; Leuschner, C. Vegetation Mitteleuropas mit den Alpen: In Ökologischer, Dynamischer und Historischer Sicht, 6; Auflage; UTB: Stuttgart, Germany, 2010.

40. Grubb, P.J.; Lee, W.G.; Kollmann, J.; Bastow Wilson, J. Interaction of Irradiance and Soil Nutrient Supply on Growth of Seedlings of Ten European Tall-Shrub Species and Fagus sylvatica. J. Ecol. 1996, 84, 827-840. [CrossRef]

41. Kunstler, G.; Curt, T.; Bouchaud, M.; Lepart, J. Growth, mortality, and morphological response of European beech and downy oak along a light gradient in sub-Mediterranean forest. Can. J. For. Res. 2005, 35, 1657-1668. [CrossRef]

42. Löf, M.; Karlsson, M.; Sonesson, K.; Welander, T.N.; Collet, C. Growth and mortality in underplanted tree seedlings in response to variations in canopy closure of Norway spruce stands. Forestry 2007, 80, 371-383. [CrossRef]

43. Petritan, A.M.; von Lupke, B.; Petritan, I.C. Effects of shade on growth and mortality of maple (Acer pseudoplatanus), ash (Fraxinus excelsior) and beech (Fagus sylvatica) saplings. Forestry 2007, 80, 397-412. [CrossRef]

44. Vernay, A.; Malagoli, P.; Fernandez, M.; Perot, T.; Améglio, T.; Balandier, P. Improved Deschampsia cespitosa growth by nitrogen fertilization jeopardizes Quercus petraea regeneration through intensification of competition. Basic Appl. Ecol. 2018, 31, 21-32. [CrossRef]

45. Brouwer, R. Some aspects of the equilibrium between overground and underground plant parts. Jaarboek van het Instituut voor Biologisch en Scheikundig onderzoek aan Landbouwgewassen 1963, 1963, 31-39.

46. Brouwer, R. Functional equilibrium: Sense or nonsense? Neth. J. Agric. Sci. 1983, 31, 335-348.

47. Shipley, B.; Meziane, D. The balanced-growth hypothesis and the allometry of leaf and root biomass allocation. Func. Ecol. 2002, 16, 326-331. [CrossRef]

48. Poorter, H.; Niklas, K.J.; Reich, P.B.; Oleksyn, J.; Poot, P.; Mommer, L. Biomass allocation to leaves, stems and roots: Meta-analyses of interspecific variation and environmental control. New Phytol. 2012, 193, 30-50. [CrossRef]

49. Annighöfer, P. Stress relief through gap creation? Growth response of a shade tolerant species (Fagus sylvatica L.) to a changed light environment. For. Ecol. Manag. 2018, 415, 139-147. [CrossRef]

50. Van Hees, A.F.M.; Clerkx, A.P.P.M. Shading and root-shoot relations in saplings of silver birch, pedunculate oak and beech. For. Ecol. Manag. 2003, 176, 439-448. [CrossRef]

51. Poorter, L.; Oberbauer, S.F. Photosynthetic induction responses of two rainforest tree species in relation to light environment. Oecologia 1993, 96, 193-199. [CrossRef]

52. Brown, C.E.; Mickelbart, M.V.; Jacobs, D.F. Leaf physiology and biomass allocation of backcross hybrid American chestnut (Castanea dentata) seedlings in response to light and water availability. Tree Physiol. 2014, 34, 1362-1375. [CrossRef]

53. Canham, C.D.; Berkowitz, A.R.; Kelly, V.R.; Lovett, G.M.; Ollinger, S.V.; Schnurr, J. Biomass allocation and multiple resource limitation in tree seedlings. Can. J. For. Res. 1996, 26, 1521-1530. [CrossRef]

54. Enquist, B.J.; Niklas, K.J. Global allocation rules for patterns of biomass partitioning in seed plants. Science 2002, 295, 1517-1520. [CrossRef] [PubMed]

55. Jarčuška, B.; Barna, M. Plasticity in above-ground biomass allocation in Fagus sylvatica L. saplings in response to light availability. Ann. For. Res. 2011, 54, 151-160.

56. Ammer, C. Growth and biomass partitioning of Fagus sylvatica L. and Quercus robur L. seedlings in response to shading and small changes in the R/FR-ratio of radiation. Ann. For. Sci. 2003, 60, 163-171. [CrossRef]

57. Legner, N.; Fleck, S.; Leuschner, C. Within-canopy variation in photosynthetic capacity, SLA and foliar N in temperate broad-leaved trees with contrasting shade tolerance. Trees 2014, 28, 263-280. [CrossRef]

58. Vile, D.; Garnier, E.; Shipley, B.; Laurent, G.; Navas, M.-L.; Roumet, C.; Lavorel, S.; Díaz, S.; Hodgson, J.G.; Lloret, F.; et al. Specific leaf area and dry matter content estimate thickness in laminar leaves. Ann. Bot.-Lond. 2005, 96, 1129-1136. [CrossRef]

59. Witkowski, E.T.F.; Lamont, B.B. Leaf specific mass confounds leaf density and thickness. Oecologia 1991, 88, 486-493. [CrossRef]

60. Landschaftsrahmenplan Landkreis Havelland. Band 2 Bestand und Bewertung. Available online: https://www.havelland.de/fileadmin/dateien/amt66/66.2_UNB/LRP/LRP_HVL_Band_2_Bestand_ und_Bewertung_Entwurf.pdf (accessed on 28 January 2019). 
61. Bundesanstalt für Landwirtschaft und Ernährung. Forstliches Vermehrungsgut_Informationen für die Praxis; Bundesanstalt für Landwirtschaft und Ernährung: Bonn, Germany, 2017; Available online: https://www.blemedienservice.de/frontend/esddownload/index/id/300/on/1164_DL/act/dl (accessed on 15 January 2019).

62. Balandier, P.; Lacointe, A.; Le Roux, X.; Sinoquet, H.; Cruiziat, P.; Le Dizès, S. SIMWAL: A structural-functional model simulating single walnut tree growth in response to climate and pruning. Ann. For. Sci. 2000, 57, 571-585. [CrossRef]

63. R Development Core Team 2013. R: A Language and Environment for Statistical Computing. Available online: http://www.R-project.org (accessed on 5 November 2017).

64. Otto, S.A.; Diekmann, R.; Flinkman, J.; Kornilovs, G.; Möllmann, C. Habitat heterogeneity determines climate impact on zooplankton community structure and dynamics. PLoS ONE 2014, 9, e90875. [CrossRef]

65. Mgcv: Mixed GAM Computation Vehicle with Automatic Smoothness Estimation. Available online: https://rdrr.io/cran/mgcv/ (accessed on 11 November 2019).

(C) 2020 by the authors. Licensee MDPI, Basel, Switzerland. This article is an open access article distributed under the terms and conditions of the Creative Commons Attribution (CC BY) license (http://creativecommons.org/licenses/by/4.0/). 